\title{
Preliminary Schedule
}

\author{
Tuesday, September 29
}

9:00 a.m. $-5: 00$ p.m. 1:00 p.m. $-5: 00$ p.m.

1:00 p.m. $-5: 00$ p.m. 7:00 p.m. $-9: 00$ p.m.

9:00 a.m. $-12: 00$ p.m.

8:00 a.m. $-7: 00$ p.m. 1:15 p.m. $-2: 30$ p.m.

2:45 p.m. $-3: 45$ p.m. 4:00 p.m- $5: 00$ p.m. 5:00 p. m. $-7: 00$ p.m. 9:30 p.m. $-11: 30$ p.m.

$7: 30$ a.m. $-5: 00$ p.m.

$8: 45$ a.m. $-9: 45$ a.m. 10:00 a.m. 4:00 p.m. 10:00 a.m. $-11: 00$ a.m.

11:00 a. m. $-12: 00$ p.m. 12:00 p.m. $-1: 30$ p.m. 1:30 p.m. $-2: 30$ p.m.

$2: 45$ p.m. $-3: 45$ p.m. 4:00 p.m. $-5: 00$ p.m. 6:00 p.m. $-10: 00$ p.m.
CE 301-Management Issues in Automation and Information Technology: CE 202-Teaching Methods for the Bibliographic Instruction Librarian. CE 203 -Basic Archives Management for Libraries.

\section{Wednesday, September 30}

CE 102 - Working Effectively with Groups.

CE 103-Establishing the College Bibliographic Instruction Program: The Director's Role.

CE 201-An Introduction to Maps in Libraries.

CE 202-Teaching Methods for the Bibliographic Instruction Librarian.

CE 203-Basic Archives Management for Libraries.

CE 501-Writing the Journal Article and Getting It Published.

CE 502-Career Advancement in Academic Librarianship: Techniques for Upward Mobility:

CE 101-Effective Supervisory Skills.

(optional) CE 502-Career Advancement in Academic Librarianship: Techniques for Upward Mobility.

\section{THURSDAY, OCTOBER 1}

CE 101-Effective Supervisory Skills.

CE 103-Establishing the College Bibliographic Instruction Program: The Director's Role.

CE 202-Teaching Methods for the Bibliographic Instruction Librarian.

CE 203-Basic Archives Management for Libraries.

CE 502-Career Advancement in Academic Librarianship: Techniques for Upward Mobility.

Conference registration.

Opening session.

Introduction and welcome.

Theme address I:

Thomas Patrick Melady, assistant secretary for postsecondary education, Department of Education.

Contributed paper sessions.

Contributed paper sessions.

Reception: Exhibits opening.

Reception: Minneapolis Public Library:

\section{Fridat, October 2}

Conference registration.

Contributed paper sessions.

Exhibits.

Theme address II:

Robert M. Rosenzweig, vice president for public affairs, Stanford University.

Discussion of theme addresses and contributed papers.

Exhilits (no conflict period).

Theme address III:

Daniel Sullivan, vice president for planning, Carleton College.

Contributed paper sessions.

Contributed paper sessions.

Reception: St. Paul Landmark Center. 
$7: 30$ a. m. $-5: 00$ p.m. $8: 45$ a.m. $-9: 45$ a.m. 10:00 a.m. $-4: 00$ p.m. 10:00 a.m. $-11: 00$ a.m.

$11: 00$ a.m. $-12: 00$ p.m. 12:00 p.m. $-1: 30$ p.m. 1:30 p.m. $-2: 30$ p.m.

$2: 45$ p. m. $-3: 45$ p. m. 4:00 p.m. $-5: 00$ p.m. 7:30 p.m. $-9: 30$ p.m.

9:15 a.m. $-11: 00$ a.m.

11:00 a.m. $-12: 00$ p.m. 1:00 p.m. $-5: 00$ p.m.
Conference registration (end of registration).

Contributed paper sessions.

Exhibits.

Theme address IV:

Paul A. Lacey, professor of English, Earlham College.

Discussion of theme addresses and contributed papers.

Exhibits (no conflict period).

Theme address $\mathrm{V}$ :

Beverly P. Lynch, university librarian, University of Illinois,

Chicago Circle.

Contributed paper sessions.

Contributed paper sessions.

Conference banquet.

Program:

Dudley Riggs' Brave New Workshop.

\section{Sunday, OCtOber 4}

Panel discussion-- "Options for the 80s"

Moderator: David C. Weber, ACRL president.

Panelists:

Sherrie S. Bergman, chair, ACRL College Libraries Section.

Marcia J. Myers, chair, ACRL Community and Junior College Libraries Section.

Joan I. Gotwals, chair, ACRL University Libraries Section. Discussion of theme addresses and contributed papers.

Tours of the Twin Cities and surrounding areas.

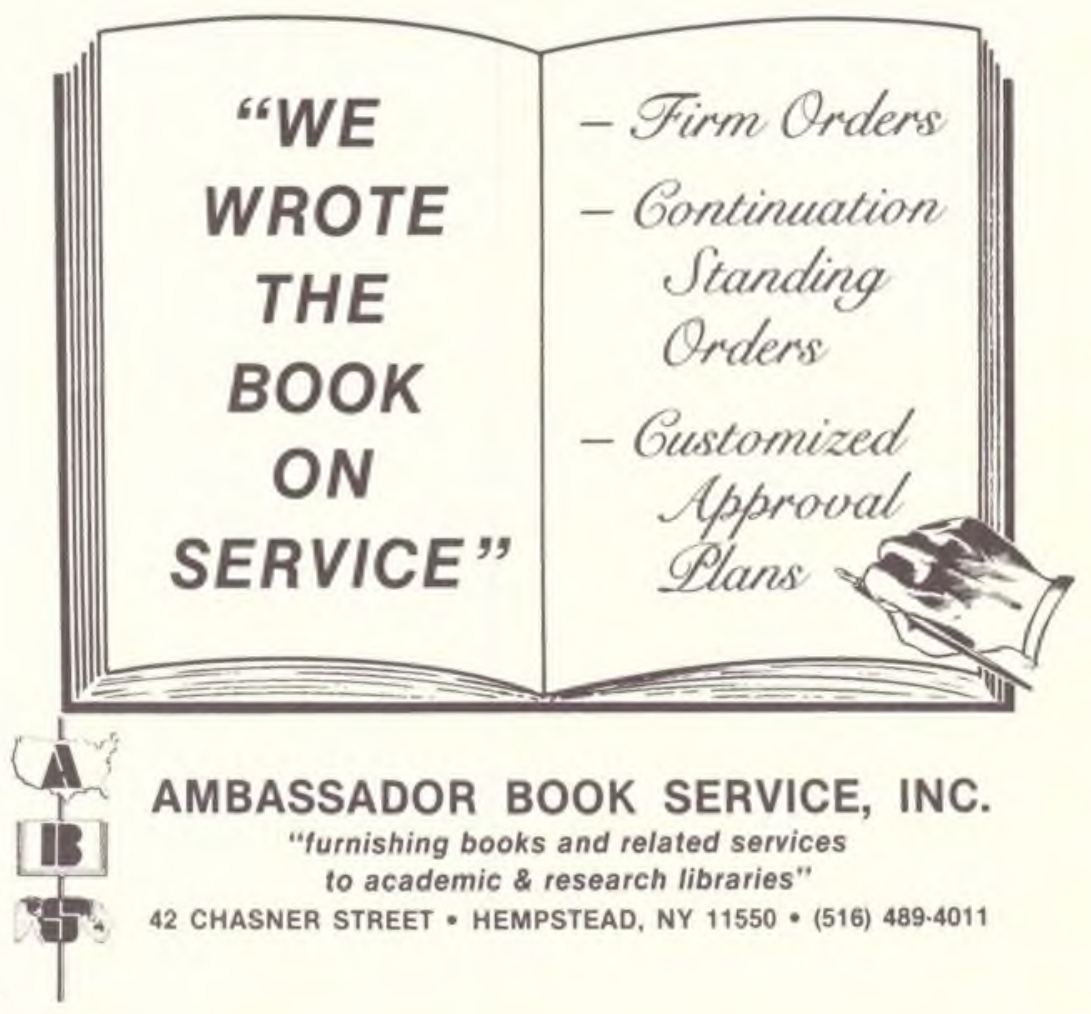




\section{ACRL Second National Conference Committee}

Conference Chair: Virgil F. Massman, executive director, James J. Hill Reference Library, St. Paul, MN 55102.

Deputy Conference Chair: John G. Berling, dean, Learning Resources Services, St. Cloud State University, St. Cloud, MN 55401.

Publicity Chair: Robert K. Bruce, head, Department of History, Minneapolis Public Library, Minneapolis, MN 55401.

Hospitality Chair: Peggy Johnson, head, Collections Processing, University of Minnesota, St. Paul, MN 55108.

Consultant: Richard D. Johnson, director of libraries, James M. Milne Library, State University College, Oneonta, NY 13820.

Audio-Visual Chair: Glenn Offermann, head librarian, Concordia College, St. Paul, MN 55104.

Secretary: Robin Overmier, Wangensteen Historical Library, University of Minnesota, Minneapolis, MN 55455.
Program Chair: Eldred Smith, director of libraries, University of Minnesota-Twin Cities, Minneapolis, MN 55455.

Fund-Raising Chair: Peter Spyers-Duran, director of libraries, California State University, Long Beach, Long Beach, CA 90840.

Contributed Papers: Michael D. Kathman, director of libraries, College of St. Benedict and St. John's University, Collegeville, MN 56321.

Exhibits Manager: Hal Espo, ACRL/ALA, Chicago, IL 60611.

ACRL Liaison: Julie Carroll Virgo, ACRL/ ALA, Chicago, IL 60611.

\section{Tennis Anyone?}

If you are interested in playing tennis at the conference or perhaps holding a conference tournament, contact Marcia Pankake, Reference Department, Wilson Library, University of Minnesota, Minneapolis, MN 55455. Court space is available at the health club facilities at the Hyatt Hotel.

ACRL members-will automatically receive registration materials in July. Non-members-detach this section and send for your registration materials.

I am not a member of ACRL.

I am interested in OPTIONS FOR THE 80s.

Please send me the preliminary program and registration materials.

Return to: OPTIONS FOR THE 80s

ACRL/ALA

50 East Huron Street

Chicago, IL 60611

(312) 944-6780

Type or print

Name

last

first

Address

street

city

state

zip code

Phone 


\section{Introducing Services for 1981}

Place your reservation today for a FREE workshop describing ISI/BIOMED ${ }^{\mathrm{TM}}$, ISI/ISTP\& ${ }^{\mathrm{rM}}$, or ISI/CompuMath ${ }^{T M}$ - the distinctive, new data bases designed to make your online searches quicker, easier, more comprehensive.

/S//B/OMED is a user-friendly system which produces high-precision biomedical bibliographies. Nearly 1,300 biomedical journals from 1979 to the present will be indexed, and users may search by article title words, source journals, cited papers, and by a new search capability-research front specialties. Research front specialty searching permits you to enter a code number for a highly specific research front and quickly retrieve a bibliography of recent articles relevant to that specialty. Over 2,700 search fronts, accessible through ISI/ $B / O M E D$, are listed in the guide which every subscriber receives.

$/ S / / / S T P_{E} B$ (Index to Scientific \& Technical Proceedings \& Books) is the only multidisciplinary online data base to scientific proceedings and books. Covering virtually every scientific and technical discipline, ISI/ISTP\&B will make retrospective and current awareness searching, bibliographic verification, and acquisitions of proceedings and multiauthored books fast and easy. Over 10,000 proceedings (from books and journals) which appear in the printed Index to
Scientific \& Technical Proceedings ${ }^{R}$, plus over 2,000 books (including annual review series), will be covered and indexed at the chapter level. Publications from 1978 to the present will be covered initially, and each month 300 new proceedings and books will be added.

IS/ CompuMath provides access to the core literature in the fields of general and applied mathematics, statistics, computer science, and operations research/ management science. Nearly 300 journals and multi-authored books will be covered from 1976 to the present. Like ISI/BIOMED, the user friendly CompuMath system will provide users with the unique research front specialty searching capability. And ISII CompuMath is only one part of a comprehensive package of information services for these disciplines. Also included in the CompuMath subscription service are a monthly current awareness edition of Current Contents ${ }^{\mathrm{B}}$ which reproduces tables of contents from recently-published journals and books; and an annual index featuring author, title word, and citation indexes.

Please place my reservation for a FREE workshop describing:

$\square I S I / B I O M E D^{\text {TM }} \square$ ISI/ISTP\&B ${ }^{\text {TN }} \square$ ISI/CompuMath ${ }^{\text {TM }}$

And send me your FREE brochure(s) about:

ISI/BIOMED $\square$ ISI/ISTP\&B

ISI/CompuMath

NAMETITLE

ORGANIZATIONDEPT

ADDRESS 
Building Library Collections

Policies and Practices in Academic Libraries

Hugh F. Cline and Loraine T. Sinnott, Educational

Testing Service

An in-depth examination of library resource allo-

cation, this book provides profiles of seven

academic libraries. The authors define the organ-

ization, structure, and function of the academic

library, and analyze fund allocation and

expenditures.

$192 p p$.

ISBN 0-669-04321.4

$\$ 15.95$

Librarians as Professionals

The Occupation's Impact on Library Work Arrangements

William Joseph Reeves, The University of Calgary Finding a paradoxical relationship between the standards of librarianship established by library associations and the actual conditions in most libraries, Reeves discusses the conditions and

circumstances where theory and practice do coincide and draws conclusions about the

nature of professionalism, organizational $192 p p$. administration, and occupational authority. ISBN 0-669-03163-1

$\$ 19.95$

Books and Publishers

Commerce against Culture in Postwar Britain

Michael Lane, University of Essex, with

Jeremy Booth, Hull College of Higher Education

Lane weighs the effects of new economic forces,

the tendency toward large multinational media

groups, and the increasingly critical role of the

editor on the British publishing industry.

$160 \mathrm{pp}$.

ISBN 0-669-03383-9

$\$ 16.95$

Publishers and Libraries:

A Study of Scholarly and Research Journals

Bernard M. Fry and Herbert S. White,

Indiana University

Based on a survey of publishers and libraries.

this book discusses their financial posture, perceptions, policies, strategies, and expectations.

192pp. ISBN 0-669-00886-9 $\$ 18.95$

\section{Resource Materials}

A Bibliography on General Deterrence Research

Deryck Beyleveld, University of

Sheffield

A comprehensive bibliography of publications in English from 1946 to 1978

that assesses research on deterrence theory, the effectiveness of crime-

control measures, and crime-deterrence policies.

500pp. $\quad$ code 03538.6 $\$ 39.95$
Computing in the Humanities edited by Peter C. Patton and Renee A. Holoien, University of

Minnesota

Focuses on current and future applications of computers to language, litera. ture, history, archaeology, and Biblical studies.

ISBN 0-669-03397.9

April 1981

Ask your wholesaler or call $800 \cdot 428-8071$.

LexingtonBooks, D. C. Heath and Company 125 Spring Street, Lexington, MA 02173 $\begin{array}{ll}\text { (617) } 862-6650 & \text { (212) } 924-6460\end{array}$

HEATH Call our toll-free number, 800 428-8071 
"... a welcome addition to the field... Highly recommended for all academic libraries."

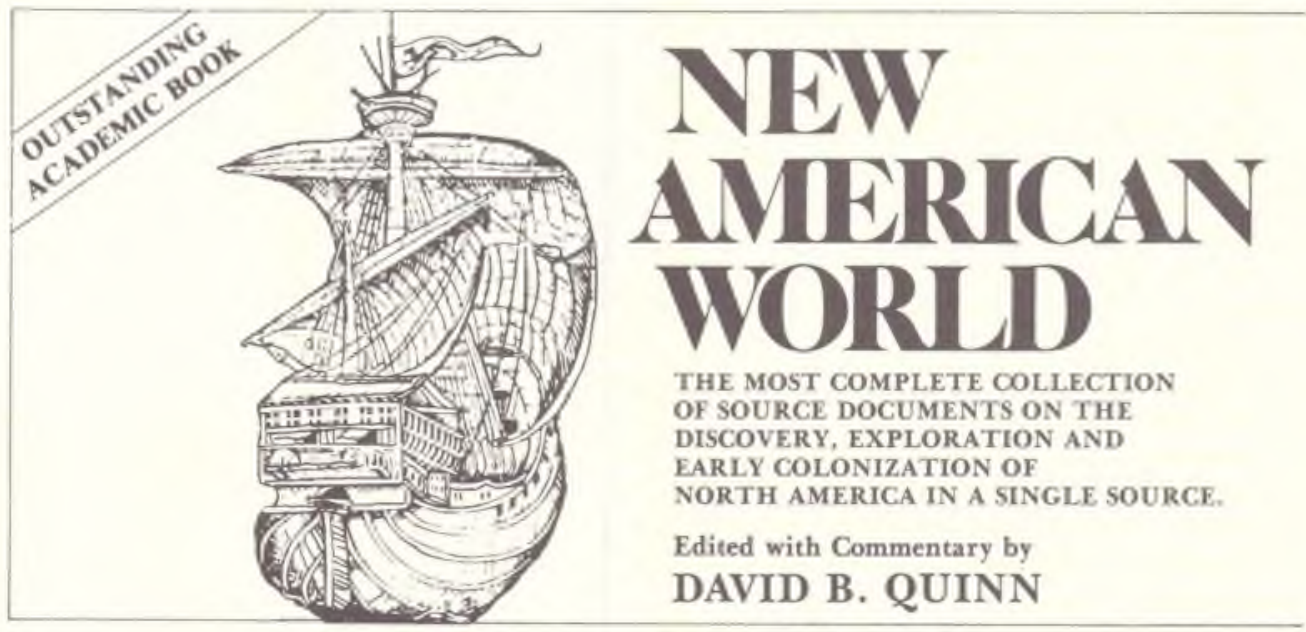

NEW AMERICAN WORLD includes documents from European archives and collections that have never before been published. These further the understanding of the economic and political motives of the European rulers, the nature of the first European contacts with North America, and the customs of the Amerindians.

The discovery, exploration and settlement of the New World comes alive in the vivid nar-

- Published for the first time, or newly translated -220 documents on European commercial enterprise, whaling, codfisheries, naval battles, politics, social customs.

- The definitive work on English exploration in the 15th and 16th centuries

- Extensive coverage of Greek, Roman Muslim concepts of the earth's surface that influenced early explorers. ratives, reports and correspondence of the European explorers who first sailed along its coasts, penetrated the interior, and exploited, enslaved, missionized, made war upon, and traded with its native inhabitants. David Beers Quinn, recognized as one of the world's leading authorities on the era, has assembled the collection, written the essays, commentaries and head notes that comprise NEW AMERICAN WORLD. All the documents are in the English language.

- Material seminal to history, geography, cartography, archaeology, sociology. and religion.

- Useful bibliographical references for all documents and a com. prehensive index
- The set comprises 5 volumes of over 2900 pages in an over-size $81 / 2 \times 11$ double column format with 851 primary documents and 147 maps.
NEW AMERICAN WORLD Five volumes: \$350.00 the set (ISBN 0-405-10759-5 Published jointly with Hector and Bye, Inc.
For our brochure or to order, please write to: ARNO PRESS/A New York Times Company Three Park Avenue, New York, N.Y. 10016 